\title{
TTR
}

Traduction, terminologie, rédaction

Anthony Cordingley and Céline Frigau Manning, eds. Collaborative Translation: From the Renaissance to the Digital Age. London, Bloomsbury, 2017, x, 260 p.

\section{Marie-Alice Belle}

Volume 31, numéro 1, 1er semestre 2018

URI : https://id.erudit.org/iderudit/1062554ar

DOI : https://doi.org/10.7202/1062554ar

Aller au sommaire du numéro

Éditeur(s)

Association canadienne de traductologie

ISSN

0835-8443 (imprimé)

1708-2188 (numérique)

Découvrir la revue

Citer ce compte rendu

Belle, M.-A. (2018). Compte rendu de [Anthony Cordingley and Céline Frigau Manning, eds. Collaborative Translation: From the Renaissance to the Digital Age. London, Bloomsbury, 2017, x, 260 p.] TTR, 31(1), 225-232.

https://doi.org/10.7202/1062554ar d'utilisation que vous pouvez consulter en ligne.

https://apropos.erudit.org/fr/usagers/politique-dutilisation/ 
cheurs «sourciers» ou "de départ», qui pourront situer l'arrivée de productions pertinentes à partir de l'index abondant des acteurs et institutions de Londres, jaugeant ainsi le cumul des ressources littéraires et culturelles à l'aune de la traduction sur la scène internationale. Du reste, l'écriture remarquablement efficace de Brodie rend la lecture agréable à tous ceux qui s'intéressent à la traduction, au théâtre et à la culture londonienne.

\section{Références}

Aaltonen Sirkku (2013). «Theatre Translation as Performance». Target, 25, 3, p. 385-406.

Bassnett, Susan (1991). «Translating for the Theatre: The Case against Performability». TTR, 4, p. 99-111.

Laera, Margherita (2014). «Introduction: Return, Rewrite, Repeat: The Theatricality of Adaptation». In Margherita Laera, dir. Theatre and Adaptation: Return, Rewrite, Repeat. Londres, Bloomsbury, p. 1-17.

Venuti, Lawrence (2008). The Translator's Invisibility, $2^{\mathrm{e}}$ éd. Londres, Routledge.

\section{Nicole Nolette UNIVERSITY OF WATERLOO}

\section{Anthony Cordingley and Céline Frigau Manning, eds. Collaborative Translation: From the Renaissance to the Digital Age. London, Bloomsbury, 2017, x, 260 p.}

The collaborative dynamics of translation projects have attracted a good deal of critical attention over the last few years. Some scholars have examined them from a historical perspective, with Belén Bistués groundbreaking Collaborative Translation and Multiversion Texts in Early Modern Europe (2013), and other recent volumes (e.g., Pender, 2017). Others have approached them from a conceptual point of view-sometimes even suggesting that translation be considered the ultimate paradigm for collaborative writing (see Alfer and Zwischenberger, 2017). Ethical and political issues have finally been brought to the fore by critics interrogating the overtly consensual discourse that often accompanies the practice, especially in digital environments (see McDonough Dolmaya,2011, 2014; Jiménez Crespo, 2017). All three aspects are represented in the collection of essays edited by Anthony Cordingley and Céline Frigau Manning, thus making it a most timely contribution to current research in the field. 
The volume is based on papers given at the conference $L a$ traduction collaborative organized in 2014 by Cordingley and Frigau Manning as part of a research project at Université Paris 8. The editors offer to approach the translation process as the "creation of a negotiated, dynamic text over which [translators] have only provisional authority" (p. 2). In their excellent introduction, they convincingly argue that "the potential of collaborative translation as a critical concept lies not [only] in its drawing attention to the different roles played by actors in a process, but in its capacity to complicate our assumptions about translation" (p. 24). Accordingly, they address the conceptual complexities raised by the notion of "collaboration" as applied to the translation process. Their suggestion is to adopt a "relational definition" of collaborative translation (p. 3) as a way of interrogating, and ultimately debunking, the myth of the solitary translator, which is itself modeled on dominant modern discourses of singular authorship. The way they historicize and contextualize discourses on collaboration offers an extremely useful introduction to recurring questions in the volume regarding translators' individual or social identities, their relations to authors and to institutional authorities, and the importance of viewing translation as a multi-layered and iterative process, in constant interaction with technologies and wider cultural and linguistic ecosystems.

The volume is divided into three parts, the first being consecrated to historical perspectives on collaborative practices, while the other two are respectively devoted to author-translator relationships and to the impact of technical and socio-political environments on collaborative practices.

In the first essay, Belén Bistué revisits Leonardo Bruni's foundational treatise De Interpretatione Recta (c.1424), focusing wittily on the "incorrect" (p.33), collaborative way to translate implicitly rejected by Bruni. Collaboration based on translators' respective language skills and fields of expertise had long been the norm in medieval and early Renaissance practice-especially in contact zones with the Arab world. It is against this historical backdrop that she examines how Bruni's treatise "negotiates an exclusive state for the individual-translator model and for the single-version text" (p. 34). In so doing, she uncovers discursive "blind spots" in Bruni's argument, whose attempt to offer a "unified understanding of translation" collapses as discourse becomes disconnected from 
practice. Bistués final invitation to "incorporate the forgotten practice of collaborative translation" (p.45) in current histories and theories of translation reads as a compelling preface to the volume as a whole.

In the next chapter, Françoise Decroisette examines her participation in a collective project to translate forty plays by the Italian eighteenth-century playwright Goldoni into French. Noting that in the case of drama, "translators are never alone, even if they happen to translate alone" (p.49), Decroisette suggests calling the translation process "shared," rather than "collaborative" (p. 49). The Goldoni translation project was in fact framed by a series of events gathering academics, critics, stage directors, actors, publishers, and institutional stakeholders. According to Decroisette, the resulting diversity in translation approaches was beneficial: it encouraged translators to engage in a constant back-and-forth movement between the page and the stage, and helped establish a translation protocol "shared by all" (p. 56). Besides highlighting the "compagnonnage" established between translators and stage directors (p. 55), Decroisette also shows how spectators were involved through various semi-staged readings that helped gage responses to the translated text, and initiate further (collective) discussions on textual and editorial strategies.

The third piece in this first section, by Jean-Louis Fournel and Jean-Claude Zancarini, focuses on French translations of early modern Italian political treatises produced as part of a translation workshop at the ENS de Fontenay Saint-Cloud. The authors draw from Meschonnic's poetics, framing their discussion as a "practicetheory of translation" (p. 68). Their approach to translation is clearly attuned to the historical and performative aspects of the texts, and guided by practical concerns, such as complementary expertise on the part of translators, a sustained effort to reach consensus, and a shared concern for oral, performative effects. The chapter also discusses HyperMachiavelli, a digital tool enabling one to interrogate and analyze early modern French translations of the Prince. The resulting historical insight into French conceptualizations of Machiavelli offers a welcome complement to the authors' discussion of their own strategies of translation and scholarly dissemination.

The essays in the second part all address cases of collaboration between translators and authors. The section opens with Patrick Hersant's "typological survey" of collaborative relations 
ranging between the extremes of carte-blanche on the one hand, and authorial appropriation on the other. Illustrated through vivid examples of contemporary literary translation in a variety of languages and contexts, the discussion goes beyond anecdotal evidence to highlight key aspects of the author-translator relationship. Besides issues of authorial intention, cultural capital, literary preservation, and (in)visibility, Hersant also underlines the complex ramifications of a process that is supposed "in an almost always unformulated way, to improve the translation itself" (p. 102). While this is true in certain cases, conflicting relationships are perhaps more relevant, Hersant argues, as they encourage us to challenge the assumption that the author knows best, and to look deeper into the linguistic, textual, and personal negotiations that are necessary to a successful, or at least, published, translation project.

While authorial appropriation represented an extreme case in Hersant's typology, it was in fact quite usual for Nabokov, as revealed by Olga Anokhina in her attentive analysis of his relationship with English and French translators of his works. Supported by rich documental evidence in the form of translation drafts and correspondence, her chapter offers a fascinating glimpse into Nabokov's creative process, and his complex, controlling rapport with his English and French translators. Anokhina subtly reveals the paradoxical nature of such relationships: Nabokov's "docile" (p.113) English translators nevertheless played a key part in the development of his identity as an English-language writer, and even of his distinct English style. In turn, the novelist's newfound notoriety became an obstacle when French publishers hired established translators who had a keen sense of their literary selves and would not comply with the author's demands.

The picture that emerges from Céline Letawe's piece, "Günter Grass and His Translators," is also tantalizingly ambivalent. While Grass was always aware of his translators and keen to initiate direct collaborations, she notes a gradual shift towards a "collective, proactive and systematic interaction" (p.130), in which efforts to facilitate translation are tinged with authorial control. Focusing on two translation seminars convened by the author at the start of his career (1978) and towards its end (2011), Letawe charts the responses of various translators, showing how they differed in their attitudes towards authorial recommendations issued in the seminars (when they participated at all). Furthermore, she uncovers 
the ambiguities of a discourse overtly encouraging translators to "become authors" (p.136) and making their work visible in the eyes of the public, yet all the while recuperating the publicity thus created to the advantage of the author's literary fame.

Translation seminars are at the heart of Abigail Lang's examination of the collaborative translation project hosted by the Abbaye de Royaumont, near Paris, from 1983 to 2000. The focus was on non-canonical, contemporary poets, and a particular interest in US poets developed over the years. Lang offers an engaging account of the genesis of the project, its interest in the US Language poets of the 1970s, and its ensuing focus on the poetics of translation. Equally interesting is her discussion of the experimental, performative aspects of the translation process, developed as a form of resistance to dominant aestheticizing trends. Ultimately, she notes, the seminars helped shape translators' approaches to the poetics of translation; they also heightened the prestige of translated poets both in France and in the US, and spurred further initiatives across Europe, thus succeeding in their ambition to "transform the solitary act [of writing] into a collective action” (p. 146).

In the third section, entitled "Environments of collaboration," Anna Zelinska-Elliot and Ika Kaminka first explore the dynamics of online collaboration among European translators of the Japanese novelist, Haruki Murakami. As the authors explain, Murakami's novelistic style, notorious for its "un-Japanese" mode tinged with English expressions, poses particular challenges when attempting to retain the "foreignness" of the source in English translation (pp. 175-176). This difficulty is redoubled by the "hegemony" (p.184) exercised by the English language, and by the author's own preference for fluent English translations. Zelinska-Elliot and Kaminka's highly original contribution shows how the creation of an online community of translators helps circumvent such cultural pressures, allowing translators to be inspired by textually creative solutions produced in other target languages than their own.

Web-based activities are also the focus of Miguel JiménezCrespo's piece, although this time from a critical perspective, since he offers an overview of recent trends in the study of translation crowdsourcing. This useful panorama covers terminological debates (should one speak of "volunteer" translation instead?) as well as conceptual definitions and typologies of web-based collaborative translation. His presentation of the main theoretical and metho- 
dological approaches to the phenomenon of crowdsourcing is a goto resource for any scholar entering this new and fast-developing subfield. Future areas of investigation are also outlined, including questions of professional identity, cognitive process, and technologically induced mutations in translators' collective behaviors.

The politics of language planning are placed center-front in Gillian Lane-Mercier's thought-provoking analysis of discourses and practices around the Government of Canada's Translation Grants Program. Examining the evolution of this case of "institutional collaboration" (p. 231) since the 1970s, Lane-Mercier reveals the discursive fault lines in public discourses presenting literary translation as a way of bridging Canada's "two solitudes" or, alternatively, as a way of protecting Canadian authors from an over-aggressive globalized publication industry. She underscores the unbalanced treatment of Canada's official languages (English and French) versus Aboriginal languages, which are sorely underrepresented despite the Council of the Arts' overt commitment to foster cultural diversity. She also points to a disturbingly constant trend in the number of grants for translation projects into French, which far outnumber those allotted to translations into English, a symptom of the relative indifference on the part of the so-called "rest of Canada" towards Quebecois literature and the culture it expresses.

In the final essay, which reads somehow as a coda to the volume, Michael Cronin offers a provocative, wide-ranging reflection on what it could mean to be a translator within a "posthumanist ecology" (p. 238) no longer centered on abusive, individualist conceptions of human self-interest. Taking his inspiration from green theory and global solidarity practices, he suggests as antidotes to the "McDonaldisation of the world" (p.239) three interrelated principles: first, place, as a way of resisting both globalized usage and abusive conflations of language and ethnicity; second, resilience, or the capacity for languages, in the face of apparent untranslatability, to survive, flourish and "invite translation" (p. 243); and finally, relatedness - a principle that Cronin extends beyond the human realm to encompass other forms of animal life, in an ultimate challenge to the "Promethean myth of the individual artificer" (p. 244). 
The collection as a whole is skillfully arranged, with essays nicely dovetailing with one another. Some are carefully documented; others (Cronin's in particular) are more speculative in kind. Shared issues nonetheless emerge quite clearly: fault lines in theoretical, cultural, or ideological discourses on collaboration; blurred boundaries between literary translation and creation; synergies or tensions arising from collaborative dynamics; and complex power relations between translators, authors, and their publishers. The emphasis on networks of production is also particularly illuminating: editors, publishers, commissioners, and other institutions sometimes loom almost as large as authors.

Noticeably, most approaches appear to be rooted in the poetics of translation outlined by Meschonnic (1999), Berman (1991) and, to a certain extent, Venuti (1995) - but not in an overly polemical or prescriptive way: discussions of translation strategies tend to favour a functional, solution-based outlook. Ethical issues are never far from the surface, ranging from questions of visibility, recognition, and remuneration, to translators' shared responsibilities in the global ecology of the language industry. The volume's only shortcoming, perhaps, is its almost exclusive focus on literary practices: the Francophone reader will find complementary perspectives in another recent collection, Traduire à plusieurs/Collaborative Translation, edited by Enrico Monti and Peter Schnyder (2018). As for Englishspeaking readers, they will perhaps be struck by the meta-discursive dimension, so to speak, of the volume. While some essays have in fact been written collaboratively, a good number have also been translated, presumably from the French, by Nicholas Manning. The texture of the original is often apparent in the translated text; if at times a bit grainy, the resulting contributions ultimately bear witness to the rich, multi-layered "closelaborations" (p. 95) that underlie the collaborative tasks of scholarly research and publication.

\section{References}

Alfer, Alexa and Cornelia Zwischenberger, eds. (2017). Translaboration:

Translation as Collaboration. Special issue of Translation and Translanguaging in Multilingual Contexts, 3, 3.

Berman, Antoine. (1991). La Traduction à la lettre, ou l'auberge du lointain. Paris, Seuil.

Bistué, Belén (2013). Collaborative Translation and Multi-Version Texts in Early Modern Europe. Aldershot, Ashgate. 
Jiménez Crespo, Miguel (2017). Crowdsourcing and Online Collaborative Translations. Expanding the limits of Translation Studies. Amsterdam/ Philadelphia, John Benjamins.

McDonough Dolmaya, Julie (2011). "The Ethics of Crowdsourcing." Linguistica Anteverpiensia, 10, p. 97-110.

McDonough Dolmaya, Julie (2014). "Analyzing the Crowdsourcing Model and Its Impact on Public Perceptions of Translation." The Translator, 18, 2, p. 167-191.

Meschonnic, Henri. (1999). Poétique du traduire. Paris, Verdier.

Monti, Enrico and Peter Schnyder, eds. (2018). Traduire à plusieurs/ Collaborative Translation. Paris, Orizons.

Pender, Patricia, ed. (2017). Gender, Authorship and Early Modern Women's Collaboration. London, Palgrave Macmillan.

Venuti, Lawrence (1995). The Translator's Invisibility. A History of Translation. London, Routledge.

Marie-Alice Belle Université De MontréAL

\section{Rudy Loock. La traductologie de corpus. Villeneuve D'Ascq, Presses universitaires du Septentrion, 2016, 261 p.}

La traductologie de corpus est un ouvrage qui vise, d'une part, à faire prendre conscience de la vaste présence des corpus électroniques dans la boîte à outils du traducteur et à amener ce dernier à les maîtriser pour mieux traduire et, d'autre part, à rappeler la variété des questions de recherche en traductologie que les corpus sont en mesure d'éclairer. Bien que ces questions aient déjà été traitées ailleurs (par ex. par Beeby et al., 2009; Laviosa, 2002; Olohan, 2004; Zanettin, 2012 et 2013; Zanettin et al., 2014), on appréciera l'excellente synthèse qu'en fait Rudy Loock et à laquelle il ajoute sa volonté de voir l'appellation "outils d'aide à la traduction» (ou «outils de TAO») s'étendre à l'ensemble des corpus électroniques. Il s'agit d'un ouvrage assez complet, rédigé dans un style clair et qui intègre des définitions, des recensions d'écrits, des présentations et des discussions de résultats d'études diverses, de même que maintes ressources utiles pour le lecteur, dont un guide pratique de compilation et d'exploitation de corpus. Il s'adresse donc à un large public qui s'intéresserait de près ou de loin à la traduction et, plus spécifiquement, aux traducteurs en exercice ou en formation et aux traductologues apprentis ou aguerris. Le livre est divisé en 